\title{
Thunderstorm-associated asthma or shortness of breath epidemic: A Canadian case report
}

\author{
AE Dennis Wardman MD FRCPC ${ }^{1}$, Dennis Stefani $\mathrm{CPHIC}^{2}$, \\ Judy C MacDonald MD FRCPC ${ }^{3}$
}

\begin{abstract}
AED Wardman, D Stefani, JC MacDonald. Thunderstormassociated asthma or shortness of breath epidemic: A Canadian case report. Can Respir J 2002;9(4):267-270.
\end{abstract}

Thunderstorm-associated asthma epidemics have been documented in the literature, but no Canadian experience has been reported. On July 31, 2000, a thunderstorm-associated epidemic of asthma or shortness of breath occurred in Calgary, Alberta. The Calgary Health Region investigated the event using diagnostic data from emergency departments, an urgent care medical clinic and patient interviews, in addition to bioaerosol counts, pollutant data and weather data reflecting atmospheric conditions at that time. On July 31, 2000 and August 1, 2000, 157 people sought care for asthma symptoms. The expected number of people to seek care for such symptoms in a $48 \mathrm{~h}$ period in Calgary is 17 . Individuals with a personal or family history of asthma, allergies or hay fever who were not taking regular medication for these conditions and who were outdoors before the storm appeared to have been preferentially affected. A stagnant air mass the day before the thunderstorm may have resulted in declining bioaerosol concentrations, and the possible accumulation of spore and pollen reservoirs within mould and plant structures. The elevated bioaerosol concentrations observed on the day of the thunderstorm may be attributed to the sudden onset of high winds during the thunderstorm, which triggered a sudden release of spores and pollens into the atmosphere, which was probably responsible for the epidemic. Several pollutant levels slightly increased on the day of the storm and possibly also played a role in symptom development. It is unclear whether an atmospheric pressure drop contributed to the release of spores and pollens.

Key Words: Air pollution; Allergens; Asthma; Bioaerosols; Epidemic; Particles; Shortness of breath; Thunderstorms

\section{Épidémie de crises d'asthme et de difficulté} respiratoire associée aux orages : exposé de cas au Canada

RÉSUMÉ : La documentation scientifique fait état d'épidémies de crises d'asthme associées aux orages, mais aucune n'avait été signalée au Canada. Toutefois, le 31 juillet 2000, il y a eu une épidémie de crises d'asthme et de difficulté respiratoire associée à un orage à Calgary. La Calgary Health

suite à la page suivante

${ }^{1}$ Department of Community Health Sciences, University of Calgary; ${ }^{2}$ Environmental Health Program, Calgary Health Region; ${ }^{3}$ Health Protection, Calgary Health Region, Calgary, Alberta

Correspondence: Mr Dennis Stefani, Environmental Health Program, Calgary Health Region, PO Box 4016, Station C, Calgary, Alberta T2T 5T1. Telephone 403-943-8049, fax 403-983-8056, e-mail DennisStefani@CalgaryHealthRegion.ca 
Region a étudié le phénomène en recueillant des données diagnostiques dans des services d'urgence, dans une clinique de soins et par des entrevues avec des patients, en plus d'obtenir des données sur les polluants et les aérosols organiques et de consulter les données météorologiques révélant les conditions atmosphériques à ce moment-là. Le 31 juillet et $1^{\mathrm{er}}$ août 2000, 157 personnes ont consulté des médecins pour des symptômes d'asthme. On évalue à 17 le nombre de personnes qui recourent normalement aux services médicaux pour ce genre de problème sur une période de 48 h, à Calgary. Les personnes ayant des antécédents personnels ou familiaux d'asthme, d'allergie ou de rhume des foins, ne prenant pas régulièrement de médicaments pour leurs troubles et se trouvant à l'extérieur avant l'orage semblent avoir été les plus touchées. Une masse d'air stagnante, la veille de l'orage, peut avoir entraîné une diminution des concentrations d'aérosols organiques ainsi qu'une accumulation de réservoirs de spores et de pollens dans les structures des plantes et des moisissures. Les concentrations élevées d'aérosols organiques, enregistrées la journée de l'orage peuvent être attribuables à l'arrivée subite de forts vents durant l'orage, entraînant la libération soudaine de spores et de pollens dans l'atmosphère, ce qui expliquerait l'épidémie. La concentration de plusieurs polluants a légèrement augmenté la journée de l'orage et a peut-être joué aussi un rôle dans l'apparition des symptômes. Par ailleurs, il n'est pas certain si la chute de pression atmosphérique a favorisé la libération de spores et de pollens.
A number of studies have reported a relationship between an increased number of asthma-related emergency department visits and thunderstorms (1-3). People afflicted are more likely to suffer from hay fever and grass pollen allergies (3). The mechanism linking asthma epidemics and thunderstorms is unclear, but associated winds that increase ambient concentrations of bioaerosols have been suggested. Air pollutants can also precipitate asthma attacks (4-5).

On July 31, 2000 and August 1, 2000 in Calgary, Alberta, 157 individuals presented to three emergency departments (EDs) and an urgent care medical clinic (UCMC) with asthma or shortness of breath symptoms after a July 31, 2000 evening thunderstorm. The Environmental Health Program of the Calgary Health Region, Calgary, Alberta investigated the outbreak.

\section{PATIENTS AND METHODS}

A descriptive study design was used. Forty-six individuals who presented to an ED or UCMC between July 31, 2000 and August 2, 2000 with a physician diagnosis of shortness of breath or asthma were randomly selected for an interview using a random number generator. The interview sought information regarding patient symptoms, personal and family history of relevant conditions, medications used and the patient's environmental scan. Participation was voluntary, and participants were advised that a report of aggregate results would be published.

Atmospheric conditions over the period leading up to and including the epidemic were examined, as defined by level of air pollutants, concentration of bioaerosols (pollens and other organic particulates) and weather data. Air quality data (levels of ozone, total hydrocarbons, nitric oxide, nitrogen oxides, nitrogen dioxide, and particulate matter $10 \mu \mathrm{m}$ or less $\left[\mathrm{PM}_{10}\right]$ and particulate matter $2.5 \mu \mathrm{m}$ in diameter or less) collected by Alberta Environment at the downtown air monitoring station were used to calculate $24 \mathrm{~h}$ average concentrations during the period of July 21, 2000 to August 2, 2000. Bioaerosol counts (pollen grains or spores counts $/ \mathrm{m}^{3}$ ) collected at a suburban area monitoring station by the Aerobiology Research Laboratory (Nepean, Ontario) for the period of July 21, 2000 to August 1, 2000 were included in the analysis. The sampler, positioned $2.44 \mathrm{~m}$ above ground, had an operating cycle of $1 \mathrm{~min}$ on and 9 min off over a $24 \mathrm{~h}$ period, and used rotation impaction technology. Particles between 3 and $100 \mu \mathrm{m}$ in diameter were identified by microscopy. Finally, data on the weather conditions associated with the thunderstorm were provided by Environment Canada.

\section{RESULTS}

On July 31, 2000 and August 1, 2000, ED or UCMC visits for asthma and shortness of breath constituted 5\% ( $n=31)$ and $17 \%(n=126)$ of all visits, respectively. In contrast, these symptoms accounted for only $1 \%(n=5)$ and $2 \%(n=12)$ of ED or UCMC visits on July 26, 2000 and August 2, 2000. Among the affected individuals sampled for interview, the median age was 31 years (range 17 to 87 years), and the median duration of symptoms was $5 \mathrm{~h}$ (range 1 to $24 \mathrm{~h}$ ) (Table 1). Interestingly, the Alberta Children's Hospital, Calgary, Alberta, which provides emergency medical care to pediatric patients, did not experience an increased number of visits for asthma or shortness of breath on these days.

Several pollutant levels increased on the day of the storm (Figure 1). Some pollutants decreased on July 26, 2000, but returned to similar or greater levels by July 31, 2000, whereas other pollutants increased daily until July 31,2000 . Of note is the significant increase in the $\mathrm{PM}_{10}$ concentration on July 31 , 2000 compared with the preceding and following days.

As with the pollutants, several bioaerosol levels were elevated on the day of the storm. Bioaerosol count data included both whole and fragmented spores and pollens, with the former the majority. Patterns similar to the pollutant levels were identified - levels decreased in the days preceding the storm but increased by July 31, 2000, or levels increased daily until July 31, 2000 (Figure 2). Bioaerosols that increased significantly from July 30, 2000 to July 31, 2000 included: algae, 25-fold; the families Amaranthaceae and Chenopodiaceae, 12-fold; the class Myxomycetes, approximately sevenfold; the genus Stemphillium, sixfold; and Helicomyces species, threefold. Of note are four fungal groups (the order Ustilaginales, Helicomyces species, the genus Stemphillium and the class Myxomycetes) that also increased. Finally, most bioaerosol concentrations, with the exception of Helicomyces species, decreased on the day after the storm (Figure 2).

Certain weather conditions should be discussed. The atmospheric pressure dropped steadily and dramatically over July 31,2000 , from $102.1 \mathrm{kPa}$ at 9:00 to $101.3 \mathrm{kPa}$ at 21:00. During the thunderstorm, winds from the northwest and west 
TABLE 1

Characteristics of $\mathbf{4 6}$ patients who presented to a Calgary, Alberta emergency department or urgent care medical clinical between July 31, 2000 and August 2, 2000 with a diagnosis of shortness of breath or asthma

\begin{tabular}{ll}
\hline Variable & $\%(\mathbf{n})$ \\
\hline Sex & \\
Male & $65(30)$ \\
Female & $35(16)$
\end{tabular}

Residence by quadrant of city

Northwest

Southwest

Northeast

$18(8)$

Southeast

Outside of Calgary

Unknown

Date of symptom onset (year 2000)

July 7

July 25

July 30

August 2

July 31

$63(29)$

August 1

Unknown

Location at onset of symptom

Home

Work

Outdoors

Unknown

medication

Asthma

35 (16)

Hay fever

$78(36)$

One or more of the above

Asthma only

Hay fever only

Allergies only

$46(21)$

One or more of the above

of asthma and/or hay fever and/or

allergies

Outside at time of storm

Exercised outdoors in previous two days

$78(36)$

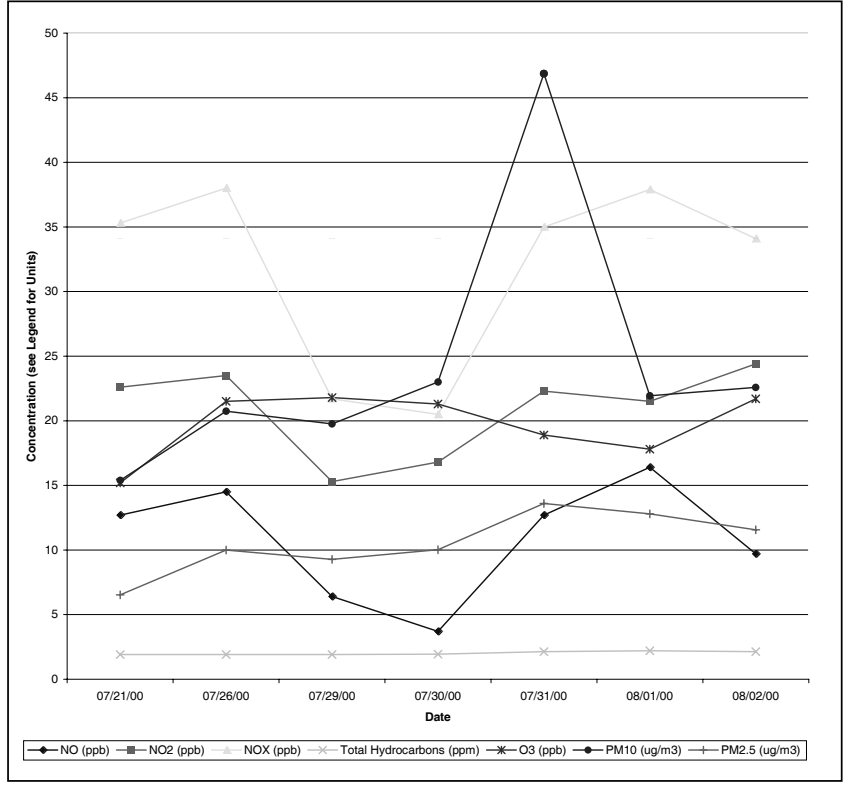

Figure 1) Twenty-four hour average ambient pollutant concentrations before, during and after the thunderstorm of July 31, 2000 (Alberta Environment Downtown Calgary Monitoring Station). NO Nitric oxide; $\mathrm{NO}_{2}$ Nitrogen dioxide; $\mathrm{NO}_{x}$ Nitrogen oxides; $\mathrm{O}_{3}$ Ozone; $\mathrm{PM}_{2.5}$ Particulate matter $2.5 \mu \mathrm{m}$ in diameter or less; $P M_{10}$ Particulate matter $10 \mu \mathrm{m}$ in diameter or less; ppb Parts per billion; ppm Parts per million

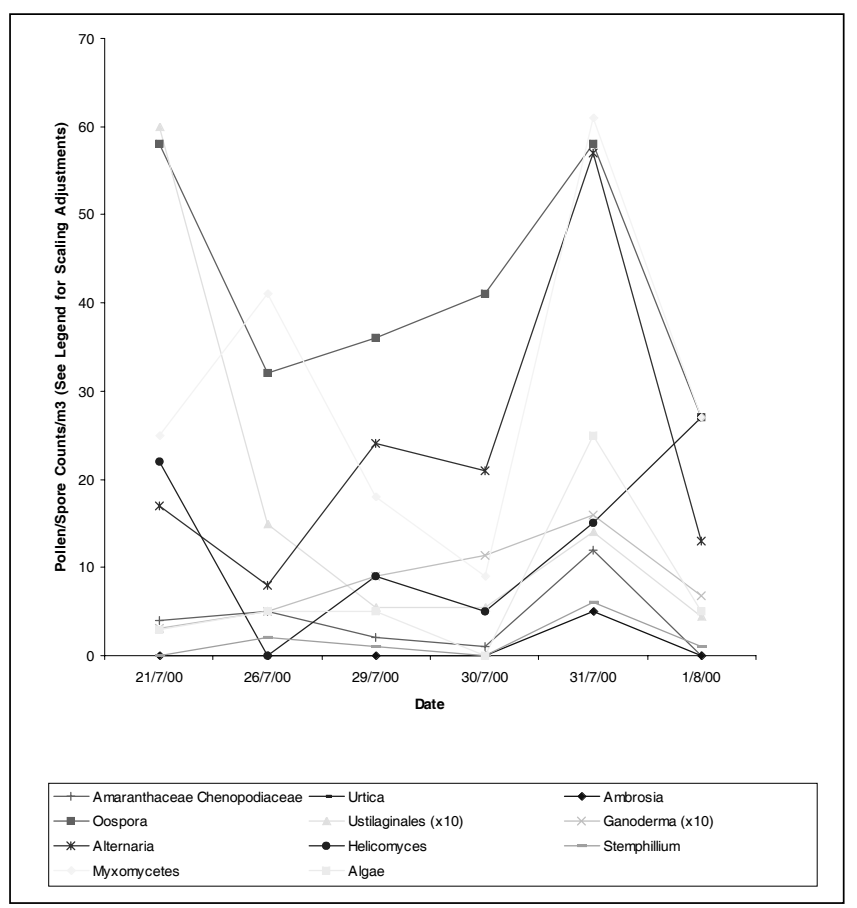

Figure 2) Twenty-four hour average bioaerosol concentrations (pollen or spore counts $/ \mathrm{m}^{3}$ ) in Calgary, Alberta

gusted up to $70 \mathrm{~km} / \mathrm{h}$. Finally, a stagnant air mass (or thermal inversion) occurred on July 31, 2000, before the thunderstorm. Information about weather conditions during previous thunderstorms, and the days before and after the storm on July 31, 2000, was not obtained. 


\section{DISCUSSION}

The present study is the first reported Canadian occurrence of epidemic asthma or shortness of breath after a thunderstorm. Peaking bioaerosol levels and windblown dust probably explain, in part, the July 31, $2000 \mathrm{PM}_{10}$ peak. These particulates might have led to symptom development in susceptible individuals not taking regular medication and who were outdoors during the storm. The stagnant air mass preceding the thunderstorm may have resulted in the accumulation of spores and pollens within moulds and plants. The sudden onset of high winds during the storm may then have triggered unusually high releases of bioaerosols into the air, provoking a physiological response in sensitive individuals.

A greater number of cases in the northwest quadrant of the city was possibly due to high levels of bioaerosols originating from a large adjacent grassland area. The preponderance of affected men may relate to their greater likelihood of being outdoors, leading to subsequent exposure to asthma triggers or allergens. Similarly, people younger than 17 years may not have been outside before and during the storm.

Other studies have demonstrated an association between asthma epidemics, thunderstorms, and increased levels of ozone and nitrogen dioxide air pollution $(4,5)$. This association was not found in the present study. However, the World Health Organization has suggested the existence of a synergistic interaction between asthma, nitrogen dioxide and bioaerosol exposure (6). Perhaps the small change in pollutant concentrations, as observed in the present study, coupled with increased bioaerosol concentrations involving weeds, fungi and algae, is significant for this asthma epidemic.

An increase in certain bioaerosols on July 31, 2000 is consistent with other studies that showed an association with increased grass pollen $(1,7)$ and mould spore (8) concentrations, and thunderstorm-linked asthma epidemics. However, our study did not identify high pollen levels for consecutive days before the thunderstorm. It is not possible to identify which of the bioaerosols is responsible for the epidemic. As well, the present study is the first to measure a marked increase in airborne algae concentrations during the thunderstorm (up to 25 units). The storm winds may have aerosolized algae from a number of lakes and ponds in and around the Calgary area. Also of interest is the increased airborne fungi concentration, because fungal spores have been implicated in previous thunderstorm-associated asthma epidemics (9).

The role of weather conditions warrants discussion. Whether the substantial drop in atmospheric pressure was a factor in the release of bioaerosols is unknown, but it deserves future study, particularly because pressure drops have been shown to be related to thunderstorm-associated asthma epidemics (1). A comparison of weather conditions during the epidemic with those during thunderstorms that were not associated with epidemics may provide useful information. More specifically, future research on temperature inversions is indicated.

\section{CONCLUSIONS}

A thunderstorm-associated epidemic of asthma or shortness of breath occurred in Calgary, Alberta on July 31, 2000. Individuals with personal or family history of asthma, allergies or hay fever who were not taking regular medications for these conditions and who were outside before the storm were preferentially affected. The stagnant air mass preceding the thunderstorm may have led to the accumulation of pollens and spores within mould and plant structures. The sudden high winds that took place during the thunderstorm may have triggered a sudden release of pollen and spores that caused the symptoms.

ACKNOWLEDGEMENTS: Dr Judy MacDonald, Mr Dennis Stefani, Ms Wendy Lau, Ms Elise Acheson and Ms Debra Mooney, all from the Calgary Health Region, Calgary, Alberta, were involved in data collection. The Health Systems Analysis Unit, Calgary Health Region, completed the data entry. Drs Wardman and MacDonald, along with Mr Stefani, completed the data analysis and manuscript preparation.

\section{REFERENCES}

1. Celenza A, Fothergill J, Kupek E, Shaw RJ. Thunderstorm associated asthma: a detailed analysis of environmental factors. BMJ 1996;312:604-7.

2. Venables KM, Allitt U, Collier CG, et al. Thunderstorm-related asthma - the epidemic of 24/25 June 1994. Clin Exp Allergy 1997;27:725-36.

3. Bellomo R, Gigliotti P, Treloar A, et al. Two consecutive thunderstorm associated epidemics of asthma in the city of Melbourne. The possible role of rye grass pollen. Med J Aust 1992;156:834-7.

4. Anderson HR, Ponce de Leon A, Bland JM, Bower JS, Emberlin J, Strachan DP. Air pollution, pollens, and daily admissions for asthma in London 1987-92. Thorax 1998;53:842-8.

5. Rossi O, Kinnula VL, Tienari J, Huhti E. Association of severe asthma attacks with weather, pollen, and air pollutants. Thorax 1993;48:244-8.

6. World Health Organization. Air Quality Guidelines, 1999. $<$ http://www.who.int/environmental_information/Air/Guidelines/ Chapter3.htm $>$ (Version current at December 7, 2001)

7. Newson, R Strachan D, Archibald E, Emberlin J, Hardaker P, Collier C. Effect of thunderstorms and airborne grass pollen on the incidence of acute asthma in England. 1990-94. Thorax 1997;52:680-5.

8. Rosas I, McCarney HA, Payne RW, et al. Analysis of the relationship between environmental factors (aeroallergens, air pollution, and weather) and asthma emergency admissions to a hospital in Mexico City. Allergy 1998;53:394-401.

9. Packe GE, Ayres JG. Asthma outbreak during a thunderstorm. Lancet 1985;2:199-204. 


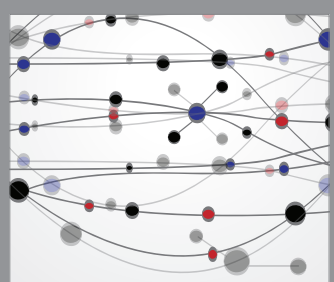

The Scientific World Journal
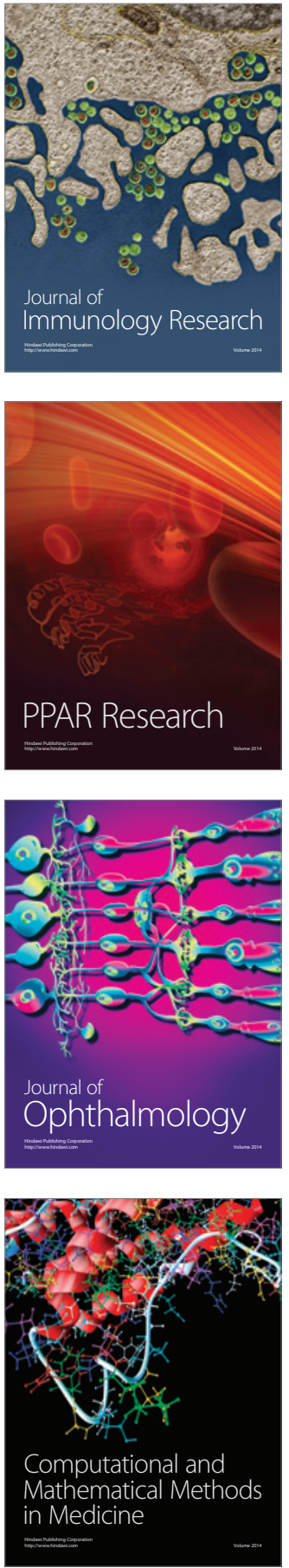

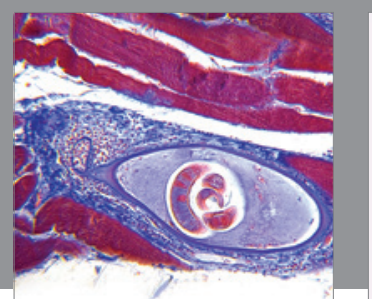

Gastroenterology Research and Practice

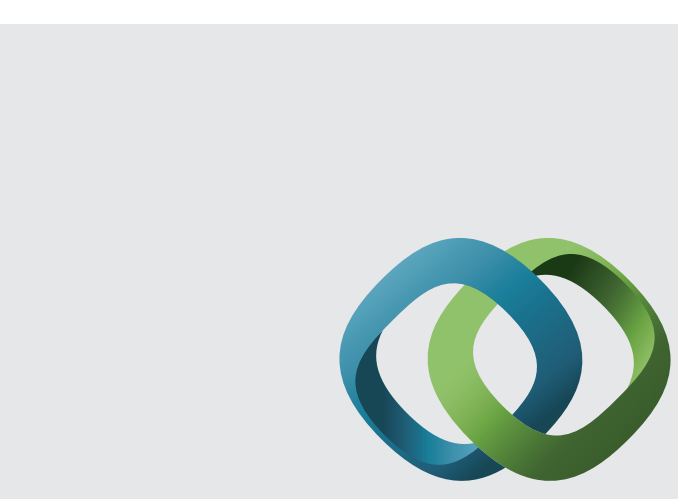

\section{Hindawi}

Submit your manuscripts at

http://www.hindawi.com
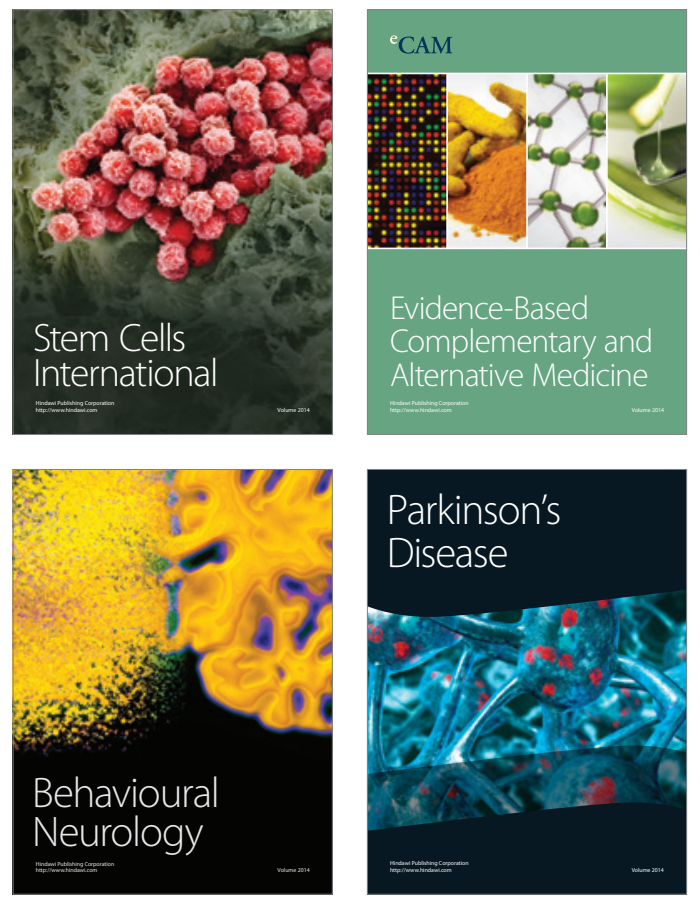
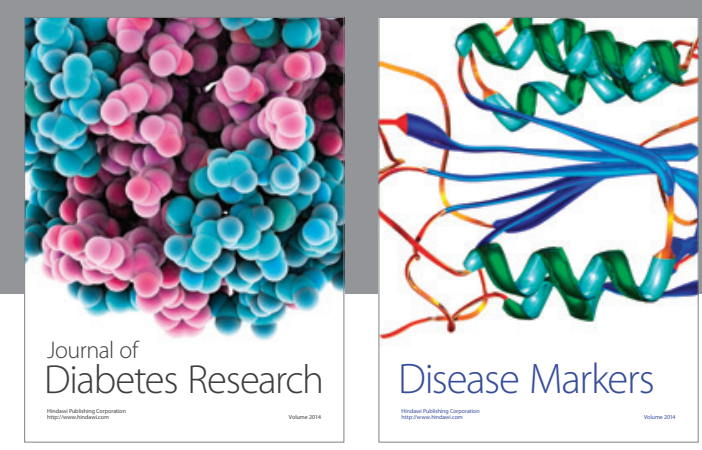

Disease Markers
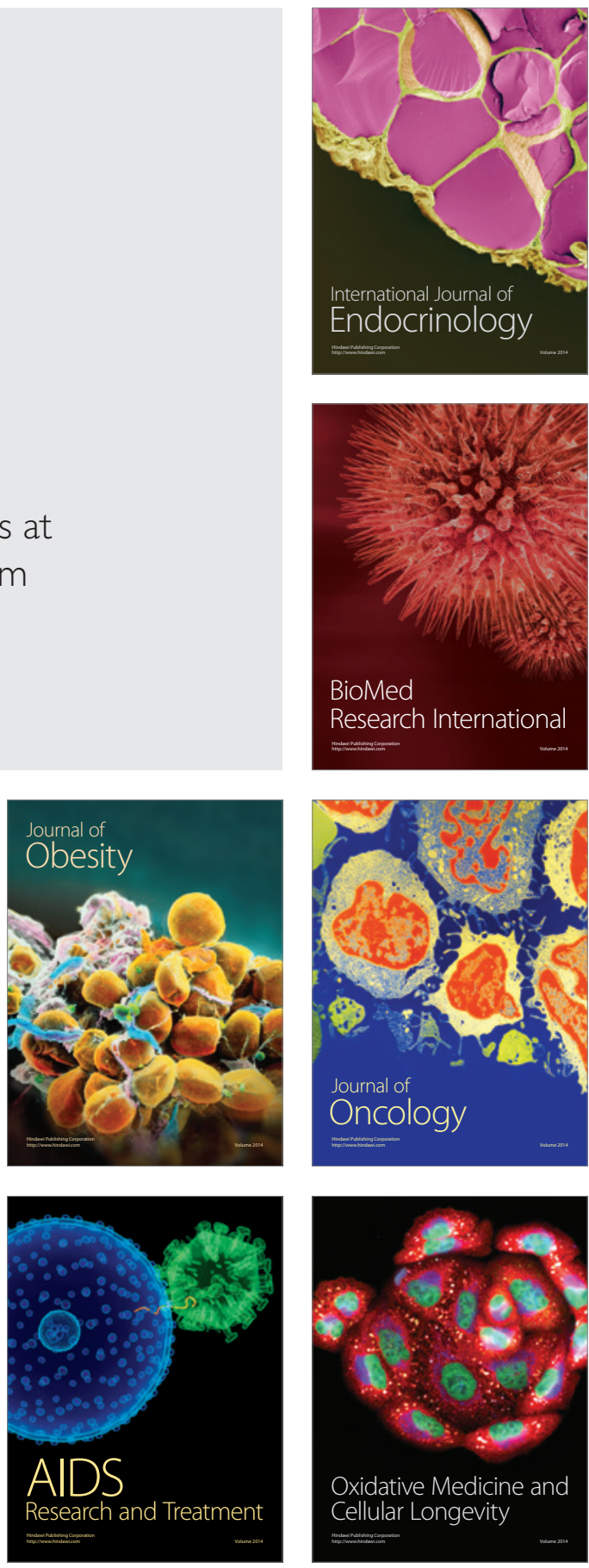